\title{
Hospital Admissions for Herpes Zoster in Portugal Between 2000 and 2010
}

\author{
Internamentos Hospitalares por Herpes Zoster em \\ Portugal entre 2000 e 2010
}

\author{
Margarida MESQUITA ${ }^{1,3}$, Filipe FROES 2,3 \\ Acta Med Port 2013 Sep-Oct;26(5):531-536
}

\section{ABSTRACT}

Introduction and Objectives: Herpes zoster and post-herpetic neuralgia increasing incidence is related to ageing. These conditions can be very debilitating and have an important impact in patients' quality of life. In an ageing population like the Portuguese, is expected that the burden of herpes zoster and post-herpetic neuralgia rises, nevertheless, a specific surveillance system for zoster does not exist in the country, and data regarding the incidence of herpes zoster and the burden of the disease in Portugal in the last decades was not found.

In Portugal, the vaccine is still not available. Scaling the burden of disease is important to support public health policies regarding zoster vaccination.

Material and Methods: We carried out a retrospective analysis from encoded information from the Portuguese Ministery of Health database for hospital admissions which included all individuals with a primary diagnosis of Herpes Zoster (IDC-9-CM 053), who were discharged between 2000 and 2010.

Results: In Portugal, between 2000 and 2010, 1706 hospital admissions with primary diagnosis of herpes zoster occurred. The majority of the patients were elderly. Eleven percent of the patients had potentially severe immunocompromise. The predominant disease was uncomplicated herpes zoster, followed by nervous system and ophthalmic herpes zoster. Mean hospital stay length was 9.3 days, increasing with age. There was a $1 \%$ case fatality rate. Considering the $2000-2009$ period and the adult population only, the average annual incidence rate of hospitalization with primary diagnosis of herpes zoster in Portugal was 1.9/100 000 inhabitants, increasing with age.

Conclusion: This study confirms that, in Portugal, severe herpes zoster is related to ageing and associated with significant morbidity, mortality and health resources allocation.

Keywords: Herpes Zoster; Hospitalization Length of Stay; Patient Admission; Patient Discharge; Portugal.

\section{RESUMO}

Introdução e Objectivos: O aumento da incidência de herpes zoster e da nevralgia pós-herpética estão associados ao envelhecimento da população. Estas patologias podem ser francamente debilitantes e ter um grande impacto na qualidade de vida dos doentes. Numa população envelhecida como a portuguesa, é esperado que o impacto do herpes zoster e da post-herpetic neuralgia aumentem. No entanto, não existe no país nenhum sistema específico de monitorização da doença e não foram encontrados dados epidemiológicos portugueses nas últimas décadas. A vacina contra o herpes zoster, já recomendada noutros países europeus, ainda não se encontra disponível em Portugal. Conhecer o impacto do herpes zoster é importante para fundamentar medidas de saúde pública relacionadas com a vacinação.

Material e Métodos: Procedeu-se a uma análise retrospetiva da base de dados da Administração Central dos Sistemas de Saúde com a informação clínica codificada dos internamentos hospitalares de todos os indivíduos com o diagnóstico principal de herpes zoster (ICD-9-CM 053) e que tiveram alta entre 2000 e 2010.

Resultados: Em Portugal, entre 2000 e 2010, ocorreram 1706 internamentos hospitalares com o diagnóstico principal de herpes zoster. A maioria dos doentes era idosa. Do total de internados, $10,6 \%$ tinham formas potencialmente graves de imunocompromisso. A doença predominante de herpes zoster sem complicações, seguido de herpes zoster do sistema nervoso e oftálmico. A duração média dos internamentos foi de 9,3 dias, aumentando com a idade. A letalidade intra-hospitalar foi de $1 \%$. Considerando o período de 2000-2009 e apenas a população adulta, a média anual da incidência dos internamentos hospitalares com o diagnóstico principal de herpes zoster foi de 1,9 por 100000 habitantes, aumentando com a idade.

Conclusão: Este estudo confirma que, em Portugal, as formas graves de herpes zoster estão relacionadas com a idade e associadas a significativa morbilidade, mortalidade e utilização de recursos em saúde.

Palavras-chave: Herpes Zoster; Hospitalização; Portugal; Tempo de Internamento.

\section{INTRODUCTION}

Herpes zoster $(\mathrm{HZ})$, also known as shingles, is the clinical manifestation of the reactivation of latent varicella zoster virus (VZV), which as a primary infection causes varicella or chickenpox..$^{1,2}$

$\mathrm{HZ}$ is a potentially serious and debilitating condition usually characterized by a unilateral vesicular rash affecting a dermatome and can be accompanied by acute pain..$^{2,3}$

The most frequent and debilitating complication of $\mathrm{HZ}$ is post-herpetic neuralgia (PHN), a persistent neuropathic pain syndrome often defined as pain that persists for $\geq 90$ days after the onset of $\mathrm{HZ}$ rash. ${ }^{2,4}$

$\mathrm{HZ}$, and particularly $\mathrm{PHN}$, can have a devastating impact

\footnotetext{
1. MD Family Medicine. MSc Geriatrics. Lisbon. Portugal.

2. Pulmonologist. Hospital Pulido Valente. Centro Hospitalar Lisboa Norte. Lisboa. Portugal.

3. Public Health. Escola Nacional de Saúde Pública. Universidade Nova de Lisboa. Lisboa. Portugal.

Recebido: 25 de Novembro de 2012 - Aceite: 15 de Abril de 2013 | Copyright @ Ordem dos Médicos 2013
} 
on patients' quality of life, interfering with daily living activities and also affecting psychological and social domains. ${ }^{5,6}$

The increasing incidence and severity of $\mathrm{HZ}$ and $\mathrm{PHN}$ can be associated with an age-related decline in VZV-specific cell-mediated immunity deriving from immunosenescense. . $^{3,7}$

Approximately $25 \%$ of people will develop $\mathrm{HZ}$ during their lifetime ${ }^{8}$ and this risk rate roughly doubles with each decade of life after 50 years $^{9}$ reaching $50 \%$ in those aged $\geq$ 85 years. ${ }^{5}$ Incidence rates range from approximately $3 / 1000$ inhabitants per year at the age of $50^{7}$ to $9 / 1000$ at the age of $65^{10}$ and $10 / 1000$ at the age of $80 .^{7,11}$

On average, $10-20 \%$ of $H Z$ patients will develop $P H N$, which can persist for years or even decades after the $\mathrm{HZ}$ rash has gone, with rates of $25-50 \%$ reported in patients over 50 years old, depending on the definition used. 2,12

The second most frequent are the ophthalmic complications. $^{13}$

Studies refer need for inpatient care for $1.3 \%$ to $4.4 \%$ of $\mathrm{HZ}$ cases, ${ }^{10,14}$ and almost $2 \%$ of $\mathrm{PHN} .{ }^{14}$ Hospitalization rates increased with age, reaching more than $19 \%$ of the cases for $80+$ patients. ${ }^{10}$ Data regarding the rate of hospitalization due to $\mathrm{HZ}$ on immunocompromised patients population was not found.

While antiviral therapy reduces the severity and duration of $\mathrm{HZ}$, it does not prevent $\mathrm{PHN}$, which remains a poorly controlled condition, even after standard therapeutic approach. ${ }^{5}$

In terms of zoster prevention, the existing vaccine showed to be safe and effective for immunization of immunocompetent individuals with no history of recent zoster. ${ }^{15}$ The preventive effect of the vaccine has been associated to a boost on host cell-mediated immunity to VZV. ${ }^{16}$

In the elderly, vaccination significantly decreased shingles incidence, the development of PHN and its severity, and reduced the burden of both diseases. ${ }^{17,18}$

The programmatic vaccination of the elderly population is actually considered cost-effective in some countries like Canada, US, UK, Netherlands and is also recommended in Austria, Australia and Greece. ${ }^{19-25}$

Portugal assists to an accelerated demographic ageing process. Portuguese individuals over 65 years old increased $18.2 \%$ in the last decade, from $16.4 \%$ of total population in 2001 to $19.0 \%$ in 2011. People reached an average life expectancy of 82.1 years for women and 76.1 for men between 2008 and $2010 .^{26}$

In an ageing population like the Portuguese, is expected that the burden of $\mathrm{HZ}$ and $\mathrm{PHN}$ rises, ${ }^{2,3,7}$ nevertheless, a specific surveillance system for zoster does not exist in the country, and data regarding the incidence of $\mathrm{HZ}$ and the burden of the disease in Portugal in the last decades was not found.

In Portugal, the vaccine is still not available. Scaling the burden of disease is important to support public health policies regarding zoster vaccination.

This study aimed to characterize the incidence of hospital admission with $\mathrm{HZ}$ between 2000 and 2010 and analyze the patient's characteristics over that period.

\section{MATERIAL AND METHODS}

In this study we analyzed retrospectively all the hospital admissions encoded with zoster (ICD-9-CM 053) as primary diagnosis in public health system hospitals in mainland Portugal, between 2000 and 2010. Patients of all ages were included.

We searched for herpes zoster with meningitis (ICD 053.00), herpes zoster with unspecified complications of the nervous system (ICD 053.10), geniculate herpes zoster (ICD 053.11), trigeminal post-herpetic neuralgia (ICD 053.12), post-herpetic polyneuropathy (ICD 053.13), herpes zoster with other complications of the nervous system (ICD 053.19), eyelid dermatitis due to herpes zoster (ICD 053.20), keratoconjunctivitis due to herpes zoster (ICD 053.21), uveitis due to herpes zoster (ICD 053.22), herpes zoster with other ophthalmic complications (ICD 053.29), external otitis due to herpes zoster (ICD 053.71), herpes zoster with other specified complications (ICD 053.79), herpes zoster with unspecified complications (ICD 053.8) and herpes zoster without complications (ICD 05.39) in the Central Administration of the Health System (ACSS) of the Portuguese Ministry of Health database.

This database contains administrative and clinical data of all admissions to National Health hospitals, which covers almost the whole resident population of mainland Portugal. The clinical information, including diagnoses and procedures, is encoded from the details of the hospital discharge report by medical staff specially trained in hospital coding, using the International Classification of Diseases, 9th Revision - Clinical Modification (ICD-9-CM).

To obtain the relevant indicators for this study we adopted a descriptive statistical analysis approach focused on variables gender, age, immune status, type of $\mathrm{HZ}$ disease, year of admission, and length of hospital stay ad outcome.

The analysis of clinical information maintained patient anonymity.

The size of the population of mainland Portugal was obtained from the Info line of the National Institute of Statistics ${ }^{26}$ and corresponds to the estimates of the resident population at the end of the year, subdivided by age and gender.

All the calculations presented were obtained using the Microsoft Excel spreadsheet and SPSS 18. Statistical tests used comprised T tests, Chi Square tests and Pearson correlation. The results of the used statistical tests were considered significant if $p<0.05$.

\section{RESULTS \\ Patient characteristics}

In Portugal, there were 1706 hospital admissions with $\mathrm{HZ}$ encoded as the primary diagnosis between 2000 and 2010, with an annual frequency that ranged from 131 episodes in 2000 to 182 in 2010, with average of 155 episodes (SD 15.2) per year (Fig. 1).

The 1706 cases with primary diagnostic of $\mathrm{HZ}$ represented $26.4 \%$ of the total 6474 episodes with $\mathrm{HZ}$ encoded as primary or secondary diagnosis during that period (Table 1). 
From the 1706 episodes, $54 \%$ of the patients were women $(\mathrm{N}=922)$ and $46 \%$ men $(\mathrm{N}=784)$.

The average age was 57.1 years (SD: 25.2), with a median age of 64 years. The average age was 55.4 (SD: 25.3) for men and 60.0 (SD: 24.8) for women ( $p<0,001)$. The greatest age was 98 years for women and 99 for men and the lowest was 0 years for the both genders (Fig. 2).

Regarding the distribution of the episodes by age group, $12.4 \%$ were pediatric patients and $31.2 \%$ were adults

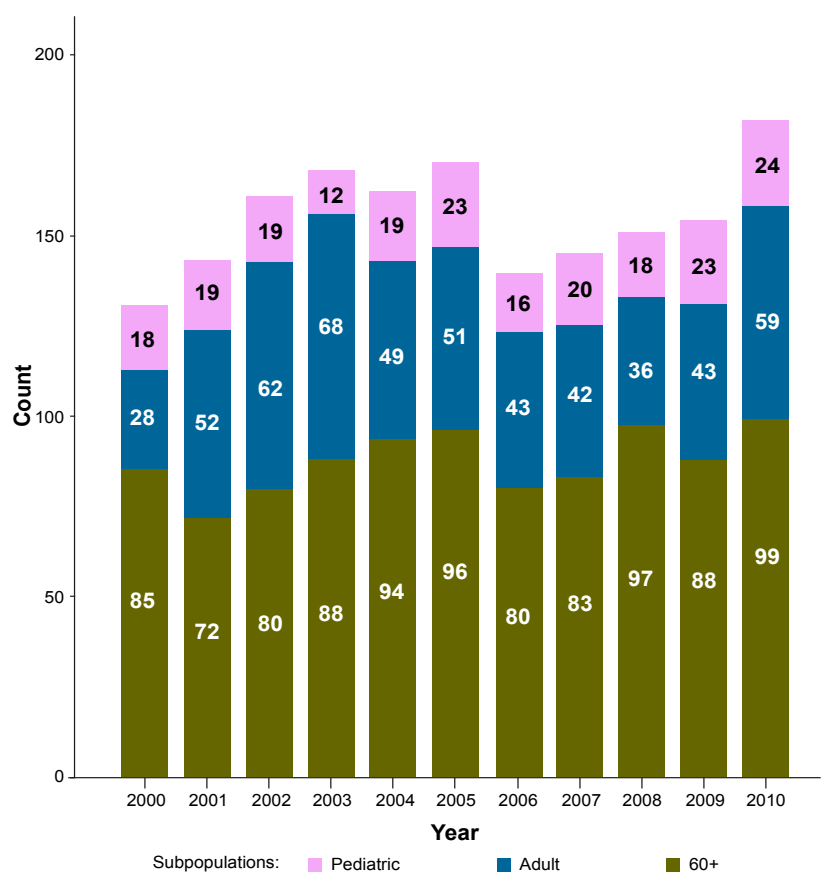

Figure 1 - Hospital admissions with primary diagnosis of $\mathrm{HZ}$ per year and subpopulation (pediatric patients were considered to be 0-17 years and adult $18-59$ years).
(18-59 years) and $56.4 \%$ were 60 years and older. From all the cases, $40.6 \%$ were patients aged 70 years and older and $19.4 \%$ were patients aged 80 years and older.

\section{Incidence rate}

Considering the $2000-2009$ period and the adult population only, the average annual incidence rate of hospitalization with primary diagnosis of $\mathrm{HZ}$ in Portugal was 1.9/100 000 inhabitants. This incidence rate showed a consistent increase with age, ranging from $0.5 / 100000$ for the 18-29 age group to $0.7 / 100000$ for the $30-49$ age group, $1.7 / 100$ 000 for the 50-64 age group, 2.8/100 000 for the 65-74 age group, 5.5/100 000 for the 75-84 age group and 8.8/100 000 for the 85 and older age group.

\section{Type of disease}

Regarding to the type of $\mathrm{HZ}$ disease, $49,5 \%$ of the episodes were for $\mathrm{HZ}$ without complications, $21.0 \%$ for nervous system disease, $16.6 \%$ for ophthalmic disease, $9.8 \%$ for $\mathrm{HZ}$ with other complications and $3.2 \%$ for otologic disease. (Table 2)

\section{Immune status}

Regarding the immune status, $10.6 \%$ of the patients were immunocompromised $(\mathrm{N}=180)$. From these, $48.9 \%$ were HIVIAIDS patients ( $\mathrm{N}=88$ ), $40.6 \%$ were transplant patients $(\mathrm{N}=73)$ and $10.6 \%$ were oncologic patients on chemotherapy $(\mathrm{N}=19)$.

From the immunocompromised patients, $56.7 \%$ were male and $42.3 \%$ were female. The average age was 41.6 years (SD 25.4) and $63 \%$ of the patients were 30 to 64 years old. When comparing to the immunocompetent patients, predominance of male gender $(p=0.02)$ and younger age

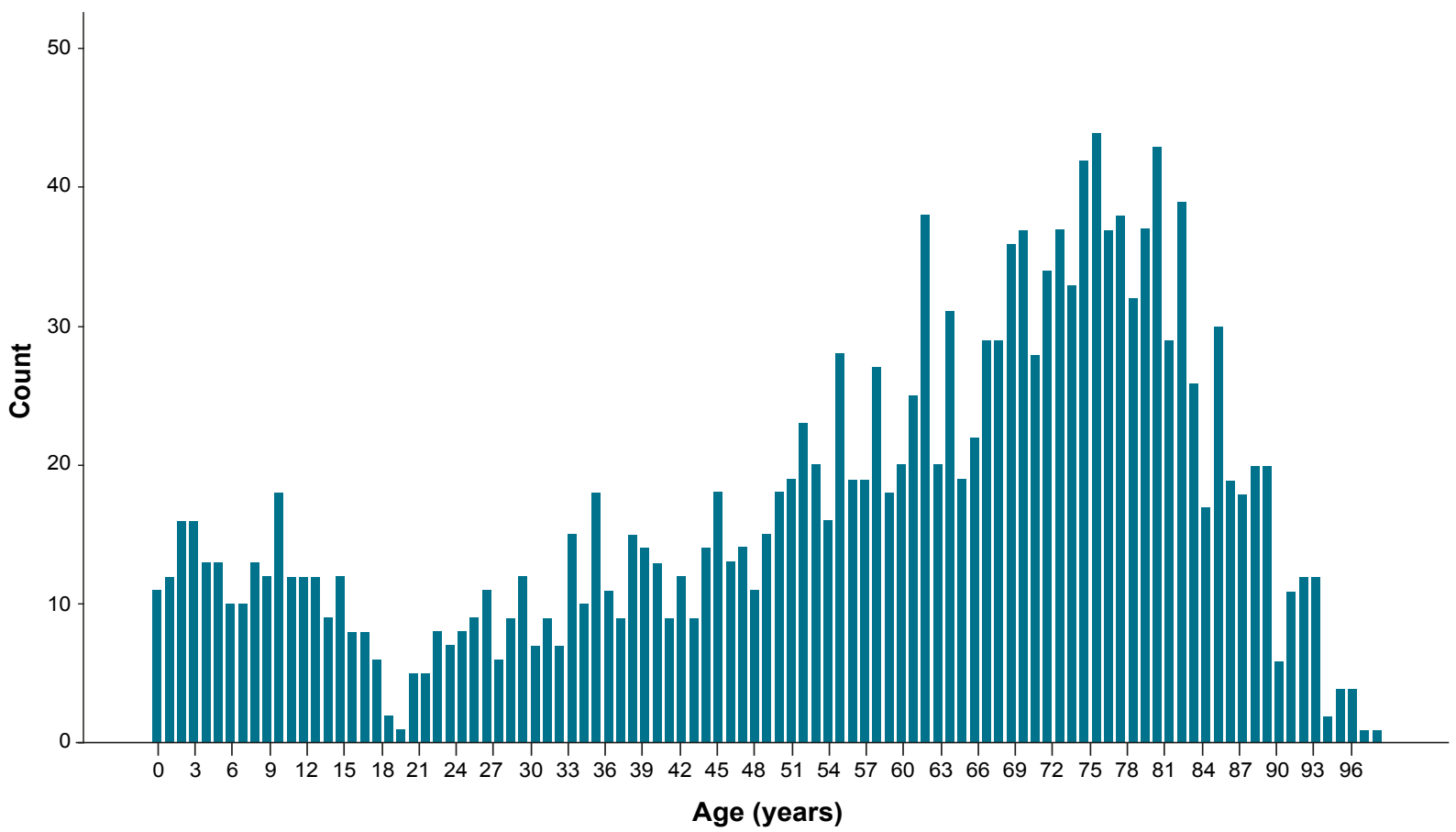

Figure 2 - Hospital admissions with primary diagnosis of $\mathrm{HZ}$ per age. 
Table 1 - Frequency of cases, gender distribution, length of hospital stay, case fatality rate and percentage of cases with $\mathrm{HZ}$ as primary diagnosis (HZ) per age group.

\begin{tabular}{|c|c|c|c|c|c|c|c|c|}
\hline \multirow{2}{*}{$\begin{array}{l}\text { Age groups } \\
\text { (years) }\end{array}$} & \multicolumn{2}{|c|}{ Gender } & \multirow{2}{*}{$\begin{array}{l}\text { Frequency } \\
\text { (N) }\end{array}$} & \multirow{2}{*}{$\begin{array}{c}\text { \% of total } \\
\text { N }\end{array}$} & \multicolumn{2}{|c|}{$\begin{array}{l}\text { Hospital stay } \\
\text { (days) }\end{array}$} & \multirow{2}{*}{$\begin{array}{c}\text { Case } \\
\text { Fatality Rate } \\
\% \\
\%\end{array}$} & \multirow{2}{*}{$\begin{array}{c}\text { Primary } \\
\text { diagnosis } \\
(\%)\end{array}$} \\
\hline & Masc. & Fem. & & & Mean & SD & & \\
\hline $0-14$ & 102 & 87 & 189 & $11.1 \%$ & 6.3 & 3.8 & $0.0 \%$ & $59.4 \%$ \\
\hline $15-29$ & 59 & 46 & 105 & $6.2 \%$ & 7.6 & 6.1 & $0.0 \%$ & $31.7 \%$ \\
\hline $30-39$ & 62 & 53 & 115 & $6.7 \%$ & 7.5 & 4.7 & $0.0 \%$ & $24.2 \%$ \\
\hline $40-49$ & 64 & 64 & 128 & $7.5 \%$ & 8.4 & 5.6 & $0.8 \%$ & $26.3 \%$ \\
\hline $50-59$ & 101 & 106 & 207 & $12.1 \%$ & 9.2 & 6.6 & $1.0 \%$ & $28.4 \%$ \\
\hline $60-69$ & 119 & 150 & 269 & $15.8 \%$ & 9.5 & 9.3 & $0.4 \%$ & $25.6 \%$ \\
\hline $70-79$ & 168 & 194 & 362 & $21.2 \%$ & 10.4 & 9.7 & $0.8 \%$ & $22.4 \%$ \\
\hline $80-89$ & 92 & 186 & 278 & $16.3 \%$ & 11.1 & 8.9 & $2.9 \%$ & $22.1 \%$ \\
\hline $90-99$ & 17 & 36 & 53 & $3.1 \%$ & 12.3 & 12.9 & $3.8 \%$ & $25.5 \%$ \\
\hline Total & 784 & 922 & 1706 & $100.0 \%$ & 9.3 & 8.2 & $1.0 \%$ & $26.4 \%$ \\
\hline
\end{tabular}

$(p<0.001)$ was evident.

From these patients, $76.6 \%$ had uncomplicated $\mathrm{HZ}(\mathrm{N}=$ 136).

\section{Hospital stay}

The average length of stay for the admissions encoded with $\mathrm{HZ}$ as the primary diagnosis was 9.3 days (SD 8,2).

The hospital stay length showed a weak positive correlation with age (Pearson $=0.195, p<0.001)$ and a significant difference between age groups $(p=0.004)$ (Table 1$)$.

Hospital stays $>17$ days (percentile 90 ) were more frequent $(p<0.001)$ for patients 65+ (OR 2.48; CI95\%1.753.52 ) and for patients with complicated $\mathrm{HZ}$ (OR 2.34; CI 95\%1.65-3.34).

The total 1706 admissions with primary $\mathrm{HZ}$ diagnosis accounted for 15898 days of inpatient treatment in Portugal during the $2000-2010$ periods. These correspond to an average of 1445 annual inpatient treatment days. Of these inpatient days, $65 \%$ were related to patients aged $60+$.

\section{Outcome}

Patients who deceased in the hospital had an average age of 76.8 (SD 13.6), being significantly older $(p<0.001)$ then the survivors.

Regarding the intra-hospitalar mortality for the admissions with primary diagnosis of $\mathrm{HZ}$, this study revealed a $1 \%$ case fatality rate $(N=17)$. From these patients, 9 were male. Ages ranged from 46 to 93 years, with mean age of 76.8 years (SD 18.1). From the deceased patients, 6 were admitted for uncomplicated $\mathrm{HZ}$; 6 for $\mathrm{HZ}$ with nervous system complications including 3 with meningitis; 4 for $\mathrm{HZ}$ with ophthalmic complications and $1 \mathrm{for} \mathrm{HZ}$ with other complications.

\section{DISCUSSION}

The last decade was marked by an evident demographic ageing, predisposing the population to an increase on $\mathrm{HZ}$ incidence and burden. On the other hand, the first zoster vaccine became available. These two motives led to several studies regarding the incidence and burden of the disease in different settings. ${ }^{10,11,14,27-30}$

This study focused on the most severe $\mathrm{HZ}$ episodes and showed that, in Portugal, during the $2000-2010$ period, 1 706 hospital admissions with primary diagnosis of $\mathrm{HZ}$ occurred. The majority of the patients were elderly. Eleven percent of the patients had potentially severe immunocompromise. The predominant disease was uncomplicated $\mathrm{HZ}$, followed by nervous system and ophthalmic HZ. Mean hospital stay length was 9.3 days, increasing with age. There was a $1 \%$ case fatality rate. Considering the 2000-2009 period and the adult population only, the average annual incidence rate of hospitalization with primary diagnosis of $\mathrm{HZ}$ in Portugal was 1.9/100 000 inhabitants, increasing with age.

Our study has potential limitations. The Portuguese Ministry of Health database is essentially administrative. The clinical information is coded from discharge documents; this work is carried out exclusively by medical doctors who 
have been formally trained in hospital coding, to make the process more rigorous. The Ministry of Health carries out regular audits, both internal and external, of this codification process.

We included patients of all ages in the study and didn't exclude patients with underlying immunosuppressive conditions. Due to methodological limitations, we could just identify as immunocompromised the patients with HIVIAIDS, transplant or oncologic disease submitted to chemotherapy. Comparing to other studies, we present a lower percentage of immunocompromised patients, fact that can be related to this methodological difference.

Data for calculating incidence rates was only accessible for adults (> 17 years) and for the period between 2000-
2010, and so we could not calculate incidence rates for pediatric patients and for year 2011.

Apart from these limitations, the methodologies are similar to those which have been used in other countries. ${ }^{10,14,27}$

One advantage of this study is that it covers a period of 10 years, a fact that can minimize the impact of years that deviate from the norm.

Comparing our study to the studies cited above, the main difference found was in the incidence rate of the episodes. We observed a 1.9/100 000 inhabitants average annual incidence rate of hospitalization with primary diagnosis of $\mathrm{HZ}$ in Portugal. Although methods were not identical, this rate is lower than the observed in all the other studies, ran-ging from 4.4/100 000 in England and Wales, ${ }^{10}$ to

Table 2 - Number of herpes zoster $(\mathrm{HZ})$ admissions, average age, average hospital stay and case fatality rate per type of $\mathrm{HZ}$ disease encoded.

\begin{tabular}{|c|c|c|c|c|c|c|c|c|c|c|}
\hline \multirow[b]{2}{*}{ ICD-9 Code } & \multirow[b]{2}{*}{$\mathrm{N}$} & \multirow[b]{2}{*}{$\%$} & \multicolumn{2}{|c|}{ Gender } & \multicolumn{2}{|c|}{ Age (years) } & \multicolumn{2}{|c|}{ Hospital Stay (days) } & \multicolumn{2}{|c|}{ Mortality } \\
\hline & & & Masc & Fem & Mean & SD & Média & SD & $\mathrm{N}$ & Rate \\
\hline $053.0 \mathrm{HZ}$ with meningitis & 93 & $5.5 \%$ & 50 & 43 & 47.9 & 26,5 & 17.1 & 14.6 & 3 & $3.2 \%$ \\
\hline 053.10 HZ with unspecified nervous system complication & 9 & $0.5 \%$ & 4 & 5 & 69.6 & 25,5 & 11.9 & 11.8 & 1 & $11.1 \%$ \\
\hline 053.11 Geniculate HZ & 122 & $7.2 \%$ & 52 & 70 & 58.2 & 20,4 & 8.5 & 6.5 & 0 & $0.0 \%$ \\
\hline 053.12 Postherpetic trigeminal neuralgia & 21 & $1.2 \%$ & 6 & 15 & 59.1 & 19,9 & 6.6 & 4.9 & 0 & $0.0 \%$ \\
\hline 053.13 Postherpetic polyneuropathy & 44 & $2.6 \%$ & 19 & 25 & 69.6 & 16,1 & 11.4 & 9 & 1 & $2.3 \%$ \\
\hline $053.14 \mathrm{HZ}$ myelitis & 3 & $0.2 \%$ & 2 & 1 & 64.7 & 18 & 28 & 4 & 0 & $0.0 \%$ \\
\hline $053.19 \mathrm{HZ}$ with other nervous system complications & 64 & $3.8 \%$ & 28 & 36 & 63.2 & 18,8 & 10 & 9 & 1 & $1.6 \%$ \\
\hline Total Nervous System HZ & 356 & $21.0 \%$ & 161 & 195 & 61.2 & 19,8 & 9.5 & 8 & 6 & $1.7 \%$ \\
\hline $053.20 \mathrm{HZ}$ dermatitis of eyelid & 148 & $8.7 \%$ & 68 & 80 & 57.8 & 27 & 8.6 & 7.2 & 3 & $2.0 \%$ \\
\hline $053.21 \mathrm{HZ}$ keratoconjunctivitis & 45 & $2.6 \%$ & 18 & 27 & 60.1 & 25,1 & 8.7 & 7 & 0 & $0.0 \%$ \\
\hline $053.22 \mathrm{HZ}$ iridocyclitis & 9 & $0.5 \%$ & 6 & 3 & 73.7 & 11,6 & 6.6 & 4 & 0 & $0.0 \%$ \\
\hline 053.29 HZ with other ophthalmic complications & 82 & $4.8 \%$ & 43 & 39 & 60.9 & 25,5 & 9.8 & 7.8 & 1 & $1.2 \%$ \\
\hline Total Ophtalmic HZ & 284 & $16.6 \%$ & 135 & 149 & 59.6 & 26 & 8.9 & 7.3 & 4 & $1.4 \%$ \\
\hline 053.71 Otitis externa due to $\mathrm{HZ}$ & 54 & $3.2 \%$ & 22 & 32 & 56.5 & 22,8 & 9.1 & 6.1 & 0 & $0.0 \%$ \\
\hline $053.79 \mathrm{HZ}$ with other specified complications & 137 & $8.0 \%$ & 70 & 67 & 53.1 & 26,8 & 11.2 & 11.8 & 1 & $0.7 \%$ \\
\hline 053.8 HZ with unspecified complication & 31 & $1.8 \%$ & 17 & 14 & 57.1 & 24,3 & 9.8 & 14.4 & 0 & $0.0 \%$ \\
\hline $053.9 \mathrm{HZ}$ without mention of complication & 844 & $49.5 \%$ & 379 & 465 & 56.4 & 25,9 & 8.2 & 5.8 & 6 & $0.7 \%$ \\
\hline Total HZ & 1706 & $100 \%$ & 784 & 922 & 57.1 & 25,2 & 9.3 & 8.2 & 17 & $1.0 \%$ \\
\hline
\end{tabular}


$8,4 / 100000$ in Spain, ${ }^{30} 10.34 / 100000$ in Italy, ${ }^{14}$ 16.1/100 000 in the US ${ }^{28}$ and 28/100 000 in Australia, in patients aged $50+.^{27}$ This difference can be due to real differences on the $\mathrm{HZ}$ incidence but, in our opinion that differences on admission criteria for $\mathrm{HZ}$ and difficulties regarding the access of the elderly to the health care system should be considered when comparing Portugal to the other studied countries.

Regarding the length of the hospital stay, our average was 9.3 days, within the average lengths observed in the other studies of 6.8 days in Australia, in 6,8 patients aged $50+,{ }^{27} 7.8$ to 8 days in Italia, ${ }^{14,29} 8,3$ days in Taiwan, ${ }^{11}$ and 10.8 days in the UK. ${ }^{10}$

Relating to case fatality rate, our average (1\%) was once more within the values observed in the other studies: $0.5 \%$ in the UK, ${ }^{10} 1.9 \%$ in the US ${ }^{28}$ and $3.6 \%$ in Spain. ${ }^{30}$

The relation between advancing age and the increased incidence of $\mathrm{HZ}$ requiring hospitalization, the increase in hospital stay length and the increased case fatality rate was observed in several studies. ${ }^{10,11,27}$ The proportion between genders and disease types was also consonant with what was observed in the other studies. ${ }^{11,27}$

\section{REFERENCES}

1. Lungu O, Annunziato PW, Gershon A, Staugaitis SM, Josefson D, LaRussa $P$, et al. Reactivated and latent varicella-zoster virus in human dorsal root ganglia. Proc Natl Acad Sci USA. 1995;92:10980-4.

2. Lukas K, Edte A, Bertrand I. The impact of herpes zoster and post-herpetic neuralgia on quality of life: patient-reported outcomes in six European countries. J Public Health. 2012;20:441-51.

3. Arvin A. Aging, immunity, and the varicella-zoster virus. $\mathrm{N}$ Engl $\mathrm{J}$ Med 2005;352:2266-7

4. Schmader K, Gnann JW Jr, Watson CP. The epidemiological, clinical, and pathological rationale for the herpes zoster vaccine. J Infect Dis. 2008;197:S207-S15

5. Schmader K. Herpes zoster in older adults. Clin Infect Dis 2001;32:1481-6.

6. Schmader KE. Epidemiology and impact on quality of life of postherpetic neuralgia and painful diabetic neuropathy. Clin J Pain. 2002;18:350-4

7. Gauthier A, Breuer J, Carrington D, Martin M, Rémy V. Epidemiology and cost of herpes zoster and post-herpetic neuralgia in the United Kingdom. Epidemiol Infect. 2009;137:38-47.

8. Yawn BP, Saddier P, Wollan PC, St Sauver JL, Kurland MJ, Sy LS. A population-based study of the incidence and complication rates of herpes zoster before zoster vaccine introduction. Mayo Clin Proc. 2007;82:1341-9.

9. Donahue JG, Choo PW, Manson JE, Platt R. The incidence of herpes zoster. Arch Intern Med. 1995;155:1605-9.

10. Brisson M, Edmunds WJ. Epidemiology of Varicella-Zoster Virus in England and Wales. J Med Virol. 2003;70:S9-14.

11. Lin $\mathrm{YH}$, Huang LM, Chang IS. Disease burden and epidemiology of herpes zoster in prevaccine Taiwan. Vaccine. 2010;28:1217-20.

12. Scott FT, Leedham-Green ME, Barrett-Muir WY, Hawrami K, Gallagher WJ, Johnson R, et al. A study of shingles and the development of postherpetic neuralgia in East London. J Med Virol. 2003;70:S24-S30.

13. Volpi A. Severe complications of herpes zoster. Herpes. 2007;14:S35-9.

14. Gialloreti LE, Merito M, Pezzotti P, Naldi L, Gatti A, Beillat M, et al. Epidemiology and economic burden of herpes zoster and post-herpetic neuralgia in Italy: A retrospective, population-based study. BMC Infect Dis. 2010;10:230

15. Arnou R, Fiquet $A$, Thomas $A$, Sadorge $C$. Immunogenicity and safety of Zostavax ${ }^{\circledR}$ approaching expiry potency in individuals aged $\geq 50$ years. Hum Vaccin. 2011;7:1060-5.

16. Gilden D. Efficacy of live zoster vaccine in preventing zoster and postherpetic neuralgia. J Intern Med. 2011;269:496-506.

17. Zussman J, Young L. Zoster vaccine live for the prevention of shingles in

\section{CONCLUSION}

This study confirms that, in Portugal, severe Herpes Zoster is related to ageing and associated with significant morbidity, mortality and health resources allocation.

Knowledge of the incidence rate of $\mathrm{HZ}$ and $\mathrm{PHN}$ in primary care settings would be fundamental to completely scale the burden of disease in our country.

\section{ACKNOWLEDGEMENTS}

The authors would like to thank the ACSS/MS and, in particular, Fátima Cardoso and Luís Faustino, for allowing us to access the database, and to Carla Nunes from Escola Nacional de Saúde Pública - Universidade Nova de Lisboa.

\section{CONFLICT OF INTEREST}

The authors have no competing interests to declare.

\section{SOURCES OF FUNDING}

This research received no specific grant from any funding agency in the public, commercial, or not for-profit sectors.

the elderly patient. Clin Interv Aging. 2008;3:241-50.

18. Schmader KE, Johnson GR, Saddier P, Ciarleglio M, Wang WW, Zhang $\mathrm{JH}$, et al. Effect of a zoster vaccine on herpes zoster-related interference with functional status and health-related quality of life measures in older adults. J Am Geriatr Soc. 2010;58:1634-41.

19. Brisson M, Pellissier JM, Camden S, Quach C, De Wals P. The potentia cost-effectiveness of vaccination against herpes zoster and post-herpetic neuralgia. Hum Vaccin. 2008;4:238-45.

20. Pellissier JM, Brisson M, Levin MJ. Evaluation of the cost-effectiveness in the United States of a vaccine to prevent herpes zoster and postherpetic neuralgia in older adults. Vaccine. 2007;25:8326-37.

21. van Hoek AJ, Gay N, Melegaro A, Opstelten W, Edmunds WJ. Estimating the cost-effectiveness of vaccination against herpes zoster in England and Wales. Vaccine. 2009;27:1454-67.

22. van Lier A, van Hoek AJ, Opstelten W, Boot HJ, de Melker HE. Assessing the potential effects and cost-effectiveness of programmatic herpes zoster vaccination of elderly in the Netherlands. BMC Health Serv Res. 2010;10:237.

23. Supreme Health Council. Vaccination Plan 2010 - Evidence-based recommendations of the Supreme Health Council. Copenhagen:SHC 2009

24. Pharmaceutical Benefits Advisory Committee - Public Summary Document - March 2008 PBAC Meeting. Adelaide:PBAC; 2008.

25. Greek Ministry of Health. 2012 National Vaccination Programme for Adults. Athens: $\mathrm{GMH} ; 2011$

26. Instituto Nacional de Estatística. Estimativas Provisórias de População Residente, Portugal, NUTS II, NUTS III e Municípios. Lisboa: Instituto Nacional de Estatística. [Consultado em 2012 Jul 2]. Disponível em https://www.ine.pt.

27. Stein AN, Britt H, Harrison C, Conway EL, Cunningham A, Macintyre $\mathrm{CR}$, et al. Herpes Zoster burden of illness and health care resource utilization in the Australian population aged 50 years and older. Vaccine. 2009;27:520-9.

28. Lin F, Hadler JL. Epidemiology of primary varicella and herpes zoster hospitalizations: The pre-varicella vaccine era. J Infect Dis. 2000;181:1897-905.

29. Gabutti G, Serenelli C, Sarno O, Marconi S, Corazza M, Virgili A. Epidemiologic features of patients affected by herpes zoster: Database analysis of the Ferrara University Dermatology Unit, Italy. Med Mal Infect. 2010;40:268-72

30. Gil A, San-Martín M, Carrasco P, González A. Epidemiology of severe varicella-zoster virus infection in Spain. Vaccine. 2004:22: 3947-51. 